\title{
Pharmacovigilance as a Tool for Ensuring Economic Security in the Russian Healthcare System
}

\author{
Antropova G.A. \\ Yaroslav-the-Wise Novgorod State University, \\ Veliky Novgorod, Russia, \\ Galina.Antropova@novsu.ru \\ Fikhtner O.A. \\ Yaroslav-the-Wise Novgorod State University, \\ Veliky Novgorod, Russia, \\ Oxana.Fikhtner@novsu.ru
}

\author{
Okonenko T.I. \\ Yaroslav-the-Wise Novgorod State University, \\ Veliky Novgorod, Russia, \\ Tatyana.Okonenko@novsu.ru \\ Veber V.R. \\ Yaroslav-the-Wise Novgorod State University, \\ Veliky Novgorod, Russia \\ Viktor.Veber@novsu.ru
}

\author{
Nemyatykh O.D. \\ Saint Petersburg State Chemical Pharmaceutical University, \\ Saint Petersburg, Russia, \\ oksana.nemyatyh@pharminnotech.com
}

\begin{abstract}
The article shows the role of the pharmacovigilance system for ensuring the economic security of the state by preventing and minimizing adverse reactions (ADRs) and side effects arising from the use of drugs. Important pharmacovigilance tools have been identified - the transmission of the received information about adverse reactions to medical and pharmaceutical specialists, as well as consumers to improve the quality of health care and patient safety in order to increase the economic efficiency of providing medical and pharmaceutical care to the population. As a result of the occurrence of undesirable reactions to the use of drugs, health deteriorates, additional treatment is required, in this regard, the recovery time and the cost of treatment increase. The growth of NR is associated with the supply from abroad of a large amount of different quality drugs, the presence of many generic drugs, which requires increased monitoring of drug safety in the postregistration period. Adverse reactions in the use of drugs in the treatment of rheumatoid arthritis were considered based on the results of monitoring of adverse reactions that occurred in patients in hospitals of the Novgorod region in the period from 2009 to 2018. To increase the participation of medical and pharmaceutical specialists in post-marketing monitoring of drug safety, it is necessary to effectively organize the participation of medical personnel: preparation of reports on the development of adverse reactions, increasing the attention of specialists regarding the safety of drug use and stimulating the transmission of messages about adverse reactions to drugs. One of the prerequisites for ensuring economic security is the availability of high-quality drug supply for the population, ensured through the
\end{abstract}

competent distribution of federal budget funds, effective targeting and budgeting in the health care sector of the Russian Federation, as well as a pharmacovigilance system capable of detecting and preventing side effects and other problems associated with drugs.

Keywords-pharmacovigilance, adverse reactions (ADR), drug safety, federal budget, safety monitoring, postmarketing research

\section{INTRODUCTION}

The use of drugs in any country is constantly increasing. The expansion of the range of drugs is due to a change in the population size, the aging process, a change in the attitude of the population to the use of drugs, this is facilitated by an increase in the quality of life of drug consumers, as well as the marketing activities of pharmaceutical companies. The experience of using drugs shows that there are practically no completely harmless drugs. All drugs can cause adverse reactions and side effects, sometimes very dangerous for human life, while the modern pharmacovigilance system plays a significant role in overcoming the negative consequences of drug use.

Thus, the activities of the national projects "Healthcare" and "Demography" [1] are aimed at solving the problems of depopulation of the population of the Russian Federation. However, a number of experts [2] believe that the allocated funds (more than 5 trillion rubles) may not be enough, 
therefore it becomes important to comply with careful measures to provide the population with medicines, to prevent possible adverse events in the provision of medical care. The redistribution of funding will be carried out in accordance with the new Decree No. 474 of July 21, 2020 "On the national development goals of the Russian Federation until 2030" [3], in which the preservation of the population, health and wellbeing of people is named as the first of the five national development goals of the country.

According to the World Health Organization (WHO), the average share of health spending in total government spending in countries ranged from $8.8 \%$ to $13.6 \%$ [4]. In low- and lower-middle-income countries, public sector availability of essential medicines was generally only $60 \%$ and $56 \%$, respectively [5]. Despite the awareness of the priority of government spending on health care, their real share in state budgets on average throughout the world is increasing slightly, and there are signs that the growth rate of overall health spending is generally slowing down [4].

An international team of researchers analyzed health care costs in 195 countries from 1995 to 2017 [6]. So, their growth was shown in 2015 to 7.9 trillion dollars, with a forecast of an increase in costs to 11 trillion dollars by 2030, however, the increase in spending does not occur in all countries. It was found that most of all financial resources per capita are spent in the USA (10.243 dollars), Switzerland (9.903 dollars), Norway (8.102 dollars), the world average was 1,048 dollars, while the cost for some African countries is about 25 dollars. In Russia, the amount of per capita spending is shown at $\$ 574$, with people paying for up to $40 \%$ of total health care costs from their own resources. Financing of healthcare in the Russian Federation is determined by the presence of market, insurance and budgetary models of healthcare, and as a result, the state needs to optimize the structure of redundant cost allocation links. There is a trend towards an increase in the share of private spending, which will contribute to a decrease in the availability of medical care [7].

In this regard, a rational approach is relevant when using insufficient financial resources when carrying out health care reforms aimed at preventing possible negative trends towards a deterioration in public health.

Measures are needed to strengthen people's positive attitude to their health, medical activity, prevention, and responsible self-medication. The promoted concept of responsible self-medication [8], on the one hand, is aimed at reducing the financial burden on the health care system in the treatment of mild diseases on their own; on the other hand, it exacerbates the problems of drug care (the appearance of side effects in case of errors in the choice of the drug and the method of its use, the development of complications, the increase in the time and cost of treatment). Consequently, it is necessary to develop a program to improve medical literacy of the population.

An integral part of the state system of measures to implement the rights of citizens to protect their health is drug assistance, the quality of the provision of which largely depends on the qualifications of medical and pharmaceutical personnel who contribute to the correct use of drugs by the population.

\section{PRoblem STATEMENT}

The current state of research on the pharmacological safety of drugs confirms the importance of studying the causes of adverse side reactions to the use of drugs and adverse events in the provision of medical care.

One of the reasons is unsafe practice and errors in the use of drugs, which cost the world community $\$ 42$ billion annually ( $1 \%$ of health care costs worldwide), while the poor quality of medical care causes additional costs of up to $\$ 1.6$ trillion in connection with with a loss of productivity [9].

So, even economically developed countries spend up to 15 $20 \%$ of their health care costs on correcting complications associated with the use of drugs [10], adverse reactions represent a significant social and economic burden [11]. Molecules of drugs become more complex, drug interactions occur with polypharmacy, the need to correct treatment requires new drug prescriptions, unforeseen side reactions develop, the number of serious complications continues to increase, adverse reactions can lead to hospitalization (on average $5.8-8.8 \%$ of all hospitalizations) [12] and even death [13].

It is important to study the role of pharmaceutical assistance in providing advisory services to the population in relation to adverse reactions of drug use [14], as well as to study the quality of drugs containing possible toxic impurities formed, for example, during improper storage or transportation, their effect on side effects, especially when using drugs that affect the body.

Preclinical and clinical studies do not allow for detecting all possible ADRs, therefore, drug safety studies continue after registration. Safety monitoring in the post-marketing period is also necessary in relation to long-term drugs, since information about ADRs or their insufficient therapeutic efficacy can be obtained in the long term [15].

In 2020, the Government of Russia [16, 17], the introduction of accelerated registration and market launch of some promising and necessary drugs and medical devices (such a registration certificate is issued with a validity period until January 1, 2021, but circulation on the territory of the Russian Federation is allowed before the expiration date). Since clinical data on these drugs will be limited, postmarketing pharmacovigilance will be of increased importance. The solution of such problems with the help of the pharmacovigilance system is observed in other states: Australia, Europe, Canada and the USA [18, 19], national security issues using pharmacovigilance capabilities are relevant for all countries of the world. However, there is a statistically significant risk that drugs approved under the fast track mechanism will receive a serious safety warning or be removed from the market compared to drugs approved under the standard registration process [20].

In the framework of the cooperation of the US Food and Drug Administration (FDA) and the European Medicines Agency (EMA) in the field of pharmacovigilance, drug safety monitoring is carried out after their approval in the US and Europe, general goals are developed for the identification and analysis of risks after drug release on the market with systematic monitoring and analysis of safety data [21]. Thus, a 
retrospective cohort study was conducted (according to FDA data) for 1997-2016, according to which 382 new drugs were approved in the United States, of which 135 (35\%) underwent the accelerated registration procedure. Changes to the instructions for therapeutic-grade drug pairs (fast track and conventional) were studied. For drugs that passed registration along the fast track, the rate of change in instructions in the safety warnings and contraindications sections was $48 \%$ higher than for drugs with a traditional approval process [22].

Expedited drug registrations increase the availability of treatments for patients, but even more careful monitoring of the safety of such drugs is needed to determine the benefit/risk ratio.

The purpose of this study: to consider the role of the pharmacovigilance system as a mechanism for detecting and assessing ADRs when using drugs to increase the costeffectiveness of providing drug care to the population using the example of analyzing ADRs that have arisen in patients when using basic drugs, NSAIDs and glucocorticosteroids in hospitals in the Novgorod region since 2009 to 2018.The use of drugs is an essential element, the basis of public health, and the more urgent is the understanding of the role of pharmacovigilance for assessing the proper handling of drugs in the interests of ensuring national security.

\section{RESEARCH METHODS}

To assess the pharmacovigilance system as a tool for ensuring economic security in the field of drug care in the Russian Federation, a systematic search of literature publications devoted to drug safety monitoring, a content analysis of indicators of civil activity pharmacovigilance system.

A retrospective analysis of reports, spontaneous messages and publications of post-marketing surveillance in the provision of drug care to patients with rheumatoid arthritis in hospitals of the Novgorod region in the period from 2009 to 2018 was carried out.

In the process of detecting ADR, as well as the peculiarities of drug interaction with other drugs, their voluntary registration by doctors and pharmaceutical specialists is of great importance [23]. The method of spontaneous messages is widely used, based on filling in a special form (notification).

In the Russian Federation, there is a National Database on adverse reactions to medicines, which contains almost 200.000 such messages; the number of messages increases annually as a result of the transition to electronic methods of submitting data on adverse reactions to Roszdravnadzor [24].

The assessment of the completeness and quality of filling in incoming messages about adverse reactions in the automated information system of pharmacovigilance is carried out using a developed coefficient similar to the VigiGrade index used in the international database of adverse reactions of the World Health Organization (VigiBase). The Russian translation of the international regulatory reference book (dictionary) in the field of drug circulation MedDra has been introduced into the format of notifications [25, 26].

In many countries, information from various social networks is widely used as an additional resource for detecting information about adverse drug reactions as part of post- registration control, since information appears immediately when an ADR occurs, i.e. much earlier than the official data is provided [27, 28, 29, 30]. However, regulatory documents are needed to regulate the process of reliably extracting ADR information from various messages. For this, the capabilities of artificial intelligence are used, recurrent neural networks are created to analyze the context of messages from users of social networks [28, 31].

Social media is a valuable source of information for the detection of ADRs for drugs used in pediatric practice, since children and pregnant women are very rarely included in clinical drug trials due to ethical issues and the risk of severe adverse events. At the same time, using the same drugs, parents and adolescents are active users of social networks [30].

The identification and prevention of ADR can be carried out by studying medical records (hospital card, outpatient card), as well as regular questioning of the patient about the detection of ADR during treatment. Special automated techniques allow to optimize this work. Thus, the Global Trigger Tool (GTT), which has been developed since 2003 at the Institute for Healthcare Improvement (IHI) based on the work of D. Classen, is recognized as the most effective system for detecting ADRs [32]. The method allows for identifying the development of ADRs and treatment complications by analyzing a random sample of patient records. The sensitivity of the method for detecting triggers with subsequent formal assessment is $94.9 \%$ [33].

\section{FINDINGS}

One of the problems solved by the pharmacovigilance system is that specialists do not report all ADRs, which is explained by a lack of time, poor knowledge of the current system, legislation; the influence of fear and guilt (doubts about the correctness of the chosen treatment, or the correctness of the dispensing of drugs at a pharmacy). In addition, some doctors and pharmaceutical specialists are sure that only safe drugs are approved for use, or they consider the identified case to be of little significance.

The detection of new ADRs of the required degree of signal reliability presupposes the timely introduction of changes in the instructions for use of this drug. With a number of reports of serious ADRs, the drug may be withdrawn from the pharmaceutical market. Thus, the non-steroidal antiinflammatory drug (NSAID) Vioxx (rofecoxib) was seized, the use of which caused severe cardiovascular complications in a large number of patients [34]

The activity of specialists in the preparation of reports on ADRs is especially important in severe, chronic diseases, for example, such as rheumatoid arthritis (RA), characterized by a high degree of disability in people of working age and significant economic damage to society.

RA is characterized by a high frequency of hospitalizations, which requires significant expenses from the state. Recently, the rheumatological service has been unable to cope with a large patient base due to insufficient funding, lack of qualified personnel, and undeveloped infrastructure. According to the Ministry of Health [35], in 2018, the human potential of the Northwestern Federal District is represented by 182 rheumatologists, of whom 111 work in St. Petersburg, and only 8 rheumatology specialists in the Novgorod region. 
Patients turn to general practitioners, whose competencies may be insufficient, which leads to longer treatment. Therefore, we analyzed the ADRs that occurred in patients with the use of basic drugs, NSAIDs and glucocorticosteroids in regional hospitals in the period from 2009 to 2018.

All patients with RA receive basic drugs, among which the drug of the first choice is the drug under the International Nonproprietary Name (INN) Methotrexate. During the study period, nausea and frequent vomiting with intramuscular injection of Vero-Methotrexate were registered in one patient in 2017 (Table). After the patient was transferred to the drug under the trade name (TN) Methotrexate-Ebewe, solution for injection $10 \mathrm{mg} / \mathrm{ml}$ (Sandoz dd, Slovenia), these complaints disappeared. The literature also contains data on poor tolerance of Vero-Methotrexate, which requires transfer to Methotrexate from other manufacturers [36].

Russian scientists studied the tolerance of Methotrexate for parenteral administration of foreign manufacturers:
Methodject (Medac GmbH, Germany); Metortritis (S.C. Romfarm Company S.R.L., Romania) and MethotrexateEbeve (Sandoz, Slovenia). All three drugs were comparable in terms of safety, tolerance, and retention parameters [37].

Leflunomide is another basic first-line anti-inflammatory drug. In 2017, also at TN Leflaid (table), complications from the gastrointestinal tract (nausea, vomiting) were registered, requiring transfer to TN Arava (Sanofi-Aventis Deutschland GmbH, Germany). In both cases, joint pain and morning stiffness increased, which, of course, led to an exacerbation of the inflammatory process and an increase in the cost of treatment.

Clinical guidelines for the treatment of RA patients also include NSAIDs. According to the Table, in 2009-2010 there were reports that patients developed anaphylactic shock after the administration of Diclofenac solution and after taking Nimesulide tablets. It should be noted that in the instructions for the drug Nise, it was noted as complications that reactions of the anaphylactoid type develop very rarely.

TABLE. MONITORING OF ADVERSE DRUg REACTIONS FOR RHEUMATOID ARTHRITIS

\begin{tabular}{|c|c|c|c|c|}
\hline INN & Trade name, dosage form & Manufacturer, country & $\begin{array}{c}\text { ATC, VED } \\
\text { code* }\end{array}$ & ADR Description \\
\hline Diclofenac & $\begin{array}{l}\text { Diclofenac, solution for } \\
\text { intramuscular injection, } 25 \\
\mathrm{mg} / \mathrm{ml}\end{array}$ & $\begin{array}{l}\text { M.J. Biopharm Pvt. Ltd, } \\
\text { India }\end{array}$ & $\begin{array}{l}\text { M01AB05 } \\
\text { yes }\end{array}$ & Anaphylactic shock, 2009 \\
\hline Nimesulide & Nise, tablets, $100 \mathrm{mg}$ & $\begin{array}{l}\text { Dr. Reddy's Laboratories } \\
\text { Ltd, India }\end{array}$ & $\begin{array}{l}\text { M01AX17 } \\
\text { no }\end{array}$ & Anaphylactic shock, 2010 \\
\hline Prednisolone & Prednisol, ampoules, $120 \mathrm{mg}$ & $\begin{array}{l}\text { Ajio Pharmaceuticals Ltd, } \\
\text { India }\end{array}$ & $\begin{array}{l}\text { H02AB06 } \\
\text { yes }\end{array}$ & $\begin{array}{l}\text { Strengthening the local reaction - } \\
\text { urticaria. Anaphylactic shock. BP 40/20, } \\
\text { severe weakness, dizziness, } 2011\end{array}$ \\
\hline Leflunomide & $\begin{array}{l}\text { Leflaid, film-coated tablets, } 20 \\
\text { mg }\end{array}$ & $\begin{array}{l}\text { Ltd “Tekhnologiya } \\
\text { lekarstv” Russia }\end{array}$ & $\begin{array}{l}\text { L04AA13 } \\
\text { yes }\end{array}$ & $\begin{array}{l}\text { Increased joint pain, morning stiffness; } \\
\text { exacerbation of the inflammatory } \\
\text { process, } 2016\end{array}$ \\
\hline Methotrexate & $\begin{array}{l}\text { Vero - Methotrexate injection, } \\
5 \mathrm{mg} / \mathrm{ml}\end{array}$ & $\begin{array}{l}\text { Ltd "VEROFARM", } \\
\text { Russia }\end{array}$ & $\begin{array}{l}\text { L01BA01 } \\
\text { yes }\end{array}$ & $\begin{array}{l}30 \text { minutes after injection, nausea, } \\
\text { frequent vomiting for two days, } 2017\end{array}$ \\
\hline Infliximab & $\begin{array}{l}\text { Flammegis, lyophilisate, for } \\
\text { solution for infusion, } 100 \mathrm{mg}\end{array}$ & $\begin{array}{l}\text { Mustafa Nevzat Ilach Sanai } \\
\text { A.Sh., Turkey }\end{array}$ & $\begin{array}{l}\text { L04AB02 } \\
\text { yes }\end{array}$ & $\begin{array}{l}\text { Abdominal pain, nausea, blood in the } \\
\text { stool, } 2017\end{array}$ \\
\hline
\end{tabular}

* ATC - Anatomical Therapeutic Chemical Classification System

VED - List of Essential and Essential Medicines

The efficacy and safety of most generic drugs of Diclofenac has not been tested in long-term randomized clinical trials, which led to a large number of ADRs.

Glucocorticosteroids are used to reduce the inflammatory response in patients. In 2011, anaphylactic shock was recorded with intravenous administration of Prednisol (Table). With intravenous administration of glucocorticosteroids, a decrease in blood pressure may occur [38], although allergic reactions, up to anaphylactic shock, are also noted in the instructions.

The INN Infliximab is used in the treatment of rheumatoid arthritis (RA). In 2017, in order to reduce financial costs, a transfer from the original drug to a biosimilar TN Flammegis made in Turkey (holder of the registration certificate Celltrion Healthcare Co., Ltd., Korea) was carried out, after which the patient's condition worsened: abdominal pain, nausea, blood in the stool. Numerous studies show the possibility of such a replacement [39, 40], however, a change in INN even within the same class can lead to a loss of clinical effect [41]. The adoption of regulatory decisions on the safety and effectiveness of drugs should be based on evidence obtained from various sources used in post-registration drug regulation, should take into account the characteristics and quantitative assessment of adverse reactions, while the data obtained show the importance of post-marketing drug regulation, are necessary to monitor the effectiveness of regulatory measures to minimize risks [42].

The introduction of new legislative measures must be accompanied by an attentive attitude to the problems of pharmaceutical manufacturers. Large multinational corporations easily adapt to the imposed restrictions (for example, price regulation), while domestic firms may not be able to cope with the fall in income, and as a result of the decrease in economic activity of the population, the supply of medical and pharmaceutical institutions with necessary drugs will be disrupted.

Continuing work in the field of improving personnel training, advanced training of medical and pharmaceutical workers, is in the need for increasing of funding for equipping medical and pharmaceutical training, as well as creating conditions for effective supervision in the development and proper use of drugs, restoration and creation of clinical bases. 


\section{CONCLUSION}

The analysis showed the need to assess the safety of drugs, which is an urgent problem of drug care at the present stage, the importance of a pharmacovigilance system that monitors the effectiveness and safety of drugs during the registration and post-registration period of drug use. However, it is necessary to improve the work of the pharmacovigilance system in the Russian Federation in terms of increasing the competence of employees at the regional level, the formation of an active civil position of the population in informing about the side effects of drugs in order to further ensure the safety of drug care in particular, and national security in general.

The lack of activity of specialists in the design of signals about the development of adverse reactions should be compensated for by reorganization measures. In order to optimize the pharmacovigilance system, it is necessary to regularly conduct training in medical and pharmaceutical organizations aimed at developing new competencies in identifying cases of $\mathrm{AD}$ or the absence of a therapeutic effect of drugs. In addition, automated accounting information systems should be introduced, as well as advanced training of personnel to work with databases. Training will allow for timely identification of adverse reactions, which will potentially reduce the economic damage from undesirable phenomena when using drugs.

The safety of the drug circulation regime, the development of measures to protect the patient from adverse reactions, and the strengthening of the social responsibility of drug manufacturers and registration certificate holders will reduce the economic burden on the budget. When carrying out drug therapy and in case of the occurrence of side effects, specialists should know the rules for registering and responding to the development of side effects, especially those that threaten human life, which will increase future economic benefits by modifying the organizational structure as an indicator of reducing economic risk.

Thus, the pharmacovigilance system is a developing dynamic socio-economic system that responds to modern challenges and has practical leverage to ensure the economic security of the state in the healthcare sector.

\section{REFERENCES}

[1] Decree of the President of the Russian Federation dated 07.05.2018 No. 04 "On national goals and strategic objectives of the development of the Russian Federation for the period up to 2024" [Ukaz Prezidenta Rossijskoj Federacii ot 07.05.2018 g. № 204 “O nacionalnyh celyah i strategicheskih zadachah razvitiya Rossijskoj Federacii na period do 2024 goda"]. (In Russ.). Retrieved from http://www.kremlin.ru/acts/bank/43027

[2] A.L. Kudrin, National projects in their current form will not lead to breakthrough economic development and qualitative transformation in the spheres that they regulate. Press release, 25 December 2019 ["Nacionalnye proekty $\mathrm{v}$ ih nyneshnem vide ne privedut $\mathrm{k}$ proryvnomu razvitiyu ekonomiki i kachestvennomu preobrazovaniyu $\mathrm{v}$ sferah, kotorye oni reguliruyut". Press-reliz, 25 dekabrya 2019 goda]. (In Russ.). Retrieved from https://ach.gov.ru/news/aleksey-kudrinoboznachil-5-klyuchevykh-problem-natsionalnykh-proektov

[3] Decree of the President of the Russian Federation of July 21, 2020 No. 474 "On the national development goals of the Russian Federation for the period up to 2030" [Ukaz Prezidenta Rossijskoj Federacii ot 21.07 .2020 g. № 474 "O nacionalnyh celyah razvitiya Rossijskoj Federacii na period do 2030 goda"]. (In Russ.). Retrieved from http://www.kremlin.ru/acts/bank/45726
[4] World health statistics 2017: monitoring health for the SDGs, Sustainable Development Goals, Geneva: World Health Organization, 2017.

[5] The Millennium Development Goals Report 2015, New York: United Nations, $2015 . \quad$ Retrieved from http://mdgs.un.org/unsd/mdg/Resources/Static/Products/Progress2015/E nglish2015.pdf

[6] Global Burden of Disease Health Financing Collaborator Network, Health sector spending and spending on HIV/AIDS, tuberculosis, and malaria, and development assistance for health: progress towards Sustainable Development Goal 3, The Lancet, 2020, vol. 391(10252), pp. 693-724. DOI: https://doi.org/10.1016/S0140-6736(20)30608-5

[7] T.G. Maksimova and Yu.N. Antokhin, "Situation and future prospects of health care financing in Russia: statistical abstract" ["Sostoyaniye i perspektivy finansovogo obespecheniya rossiyskogo zdravookhraneniya: kratkiy statisticheskiy obzor"], Bulletin of the St. Petersburg State University of Economics [Journal "Izvestiâ Sankt-Peterburgskogo gosudarstvennogo èkonomičeskogo universiteta"], 2017, vol. 1-2(103), pp. 173-178. (In Russ.).

[8] S.N. Tolpygina, S.Y. Martsevich, A.V. Kontsevaya and O.M. Drapkina, "Responsible Self-Care - the Fundamental Principles and Place in the Modern Russian Healthcare System" ["Otvetstvennaya zabota o sebe osnovopolagayushchiye printsipy i mesto $\mathrm{v}$ sovremennoy sisteme zdravookhraneniya Rossii"], Rational Pharmacotherapy in Cardiology [Ratsional'naya farmakoterapiya v kardiologii], 2018, vol. 14(1), pp. 101-110. (In Russ.). DOI: https://doi.org/10.20996/1819-6446-201814-1-101-110

[9] WHO Global Patient Safety Challenge: Medication Without Harm Geneva: World Health Organization, 2017. Retrieved from http://apps.who.int/iris/bitstream/10665/255263/1/WHO-HIS-SDS2017.6eng.pdf?ua $=1 \& u a=1$

[10] V.B. Gerasimov, S.V. Lukyanov, A.A. Babakhin and S.A. Kalinichev, "Side effects of drugs" [Pobochnyye effekty lekarstvennykh sredstv], Remedium. Magazine about the Russian market of medicines and medical equipment [Remedium. Zhurnal o rossijskom rynke lekarstv i medicinskoj tekhnike], 2005, vol. 1-2, pp. 32-36. (In Russ.).

[11] A.M. Strizhevskaya, E.G. Golovnya, I.S. Kuleshova, A.Z. Dzampaeva and V.N. Baykova, "Therapeutic drug monitoring of methotrexate after its administration in high doses for osteosarcoma treatment in children", Pharmacokinetics and Pharmacodynamics, 2016, vol. 1, pp. 48-53. (In Russ.).

[12] D. Walsh, A. Lavan, A.M. Cushen and D.Williams, "Adverse drug reactions as a cause of admission to a Dublin-based university teaching hospital", Ir. J. Med. Sci., 2015, vol. 184, pp. 441-447. DOI: https://doi.org/10.1007/s11845-014-1140-1

[13] V.K. Lepakhin, A.S. Kazakov and A.V. Astakhova, "Pharmacoepidemiological study of adverse reactions associated with drug interactions" [Farmakoepidemiologicheskoye issledovaniye nezhelatel'nykh reaktsiy, svyazannykh s vzaimodeystviyem lekarstvennykh sredstv]. Clinical pharmacology and therapy [Klinicheskaya farmakologiya i terapiya], 2013, vol. 22(4), pp. 92-96. (In Russ.).

[14] V.P. Salomón and Y.M., Berroteran "Pharmaceutical care practice: a useful tool in pharmacovigilance", Drug Safety, 2008, vol. 31, p. 885 DOI: https://doi.org/10.2165/00002018-200831100-00179

[15] C. Versantvoort, M. Maliepaard and F. Lekkerkerker, "Generics: what is the role of registration authorities", Neth. J. Med., 2008, vol. 66(2), pp. 62-66.

[16] Decree of the Government of the Russian Federation of April 3, 2020 No. 441 "On the peculiarities of the circulation of medicinal products for medical use, which are intended for use in conditions of threat of occurrence, occurrence and liquidation of an emergency and for organizing the provision of medical assistance to persons affected by situations, prevention of emergencies, prevention and treatment of diseases that pose a danger to others, diseases and injuries resulting from exposure to adverse chemical, biological, radiation factors" [Postanovlenie Pravitelstva RF ot 3 aprelya 2020 g. № 441 “ $\mathrm{Ob}$ osobennostyah obrashcheniya lekarstvennyh preparatov dlya medicinskogo primeneniya, kotorye prednaznacheny dlya primeneniya $\mathrm{v}$ usloviyah ugrozy vozniknoveniya, vozniknoveniya i likvidacii chrezvychajnoj situacii i dlya organizacii okazaniya medicinskoj pomoshchi licam, postradavshim $\mathrm{v}$ rezultate chrezvychajnyh situacij, preduprezhdeniya chrezvychajnyh situacij, profilaktiki i lecheniya zabolevanij, predstavlyayushchih opasnost dlya okruzhayushchih, 
zabolevanij i porazhenij, poluchennyh $\mathrm{v}$ rezultate vozdejstviya neblagopriyatnyh himicheskih, biologicheskih, radiacionnyh faktorov"]. (In Russ.). Retrieved from https://www.garant.ru/products/ipo/prime/doc/73750814/

[17] Decree of the Government of the Russian Federation of 03.04.2020 No. 430 "On the peculiarities of the circulation of medical devices, including state registration of a series (batch) of a medical device" [Postanovlenie Pravitelstva RF ot 03.04.2020 № 430 “Ob osobennostyah obrashcheniya medicinskih izdelij, v tom chisle gosudarstvennoj registracii serii (partii) medicinskogo izdeliya"]. (In Russ.). Retrieved from https://www.alta.ru/tamdoc/20ps0430/

[18] M. Linger and J. Martin, "Pharmacovigilance and expedited drug approvals", Australian Prescriber, 2018, vol. 41(2), pp. 50-53. DOI: https://doi.org/10.18773/austprescr.2018.010

[19] J. Martin and G. Shenfield, "The hazards of rapid approval of new drugs". Australian Prescriber. 2016, vol. 39(1):2-3. DOI: https://doi.org/10.18773/ austprescr.2016.005

[20] J. Lexchin, "Post-market safety warnings for drugs approved in Canada under the notice of compliance with conditions policy". British Journal of Clinical Pharmacology, 2015, vol. 79, pp. 847-59. DOI: https://doi.org/10.1111/bcp.12552

[21] G.J. Dal Pan and P.R. Arlett, "The US Food and Drug Administration European Medicines Agency Collaboration in Pharmacovigilance: Common Objectives and Common Challenges", Drug Saf, 2015, vol. 38(1), pp. 13-15. DOI: https://doi.org/10.1007/s40264-014-0259-3

[22] S.R. Mostaghim, J.J. Gagne and A.S. Kesselheim, "Safety related label changes for new drugs after approval in the US through expedited regulatory pathways: retrospective cohort study", BMJ, 2017, vol. 358:j3837. DOI: https://doi.org/10.1136/bmj.j3837

[23] N. Bhati, S. Kannan and P.P. Khosla, "Good pharmacovigilance practice: Need of the hour from pharmaceutical companies", Perspect. Clin. Res, 2015, vol. 6(3), pp. 171-172. DOI: https://doi.org/10.4103/2229-3485.159944

[24] S.V. Glagolev, K.V. Gorelov and D.A. Chizhova, "Development of the pharmacovigilance system in the Russian Federation" ["Razvitiye sistemy farmakonadzora $\mathrm{v}$ Rossiyskoy Federatsii"]. Bulletin of Roszdravnadzor [Vestnik Roszdravnadzora]. 2019, vol. 2. pp. 72-77. (In Russ.).

[25] MedDRA (Medical Dictionary for Regulatory Activities), 2020. Retrieved from https://www.meddra.org

[26] M.A. Murashko, "Rosdravnadzor today" ["Roszdravnadzor segodnya"], Bulletin of Roszdravnadzor [Vestnik Roszdravnadzora], 2019, vol. 2, pp. 9-19. (In Russ.).

[27] I.I. Snegireva, A.S. Kazakov, Ye.Yu.Pasternak, K.E. Zatolochina and T.V. Romanova, "Social media as a source of drug safety information and how to extract it" ["Sotsial'nyye media kak istochnik informatsii o bezopasnosti lekarstvennykh sredstv i sposoby yeye izvlecheniya"] Safety and risk of pharmacotherapy [Bezopasnost' i risk farmakoterapii], 2017, vol. 5 (4), pp. 174-181. (In Russ.).

[28] R. Abdellaoui, S. Schuck, N. Texier and A. Burqun, "Filtering entities to optimize identification of adverse drug reaction from social media: how can the number of words between entities in the messages help?" JMIR Public Health Surveill, 2017, vol. 3(2), e36. DOI: https://doi.org/10.2196/publichealth.6577

[29] K. Lee, A. Qadir, S.A. Hasan, V. Datla, A. Prakash, J. Liu and O. Farri, "Adverse drug event detection in tweets with semi-supervised convolutional neural networks", in Proceedings of the 26th International Conference on World Wide Web, 2017, pp. 705-714. DOI: https://doi.org/10.1145/3038912.3052671

[30] S. Matsuda, K. Aoki, S. Tomizawa, M. Sone, R. Tanaka., H. Kuriki and Yo. Takanashi, "Analysis of Patient Narratives in Disease Blogs on the
Internet: An Exploratory Study of Social Pharmacovigilance", JMIR Public Health Surveill, 2017, vol. 3(1), e10. DOI: https://doi.org/10.2196/publichealth.6872

[31] A. Cocos, A.G. Filks and A.J. Masino, "Deep learning for pharmacovigilance: recurrent neural network architectures for labeling adverse drug reactions in Twitter posts", J Am Med Inform Assoc, 2017, vol. 26(6), pp. 580-581. DOI: https://doi.org/ 10.1093/jamia/ocy192

[32] D.C. Classen, R.C. Lloyd, L. Provost, F.A. Griffin and R. Resar. "Development and evaluation of the Institute for Healthcare Improvement Global Trigger Tool”. Journal of Patient Safety, 2008, vol. 4(3), pp. 169-177.

[33] M.V. Zhuravleva, B.K. Romanov, G.I. Gorodetskaya, O.V. Muslimova, V.S. Krysanova and E.Yu. Demchenkova, "Topical issues of drug safety, possibilities of improving of pharmacovigilance", Safety and Risk of Pharmacotherapy [Bezopasnost' i risk farmakoterapii], 2019, vol. 7(3), pp. 109-119. (In Russ.). DOI: https://doi.org/10.30895/23127821-2019-7-3-109-119

[34] "Vioxx: an unequal partnership between safety and efficacy". The Lancet, 2004, vol. 364(9442), pp. 1287-88. DOI: https://doi.org/10.1016/S0140-6736(04)17198-5

[35] Statistical Book 2018. Resources and activities of medical healthcare organizations. Moscow, 2019 [Statisticheskij sbornik 2018 god. Resursy i deyatelnost medicinskih organizacij zdravoohraneniya. Moskva, 2019]. (In Russ.). Retrieved from https://minzdrav.gov.ru/ministry/61/22/stranitsa-979/statisticheskie-iinformatsionnye-materialy/statisticheskiy-sbornik-2018-god

[36] E.Y. Pasternak, K.E. Zatolochina, B.K. Romanov, R.N. Alyautdin, N.D. Bunyatyan and I.L. Asetskaya, "Evaluation of interchangeability of drugs used in pediatrics with accounting safety", Scientific journal Advances in current natural sciences, 2015, vol. 6, pp. 46-51. (In Russ.).

[37] D.E. Karateev, E.L. Luchikhina, G.I. Gridneva and N.V. Demidova, "The use of subcutaneous methotrexate from various manufacturers in real clinical practice: a comparative study", Almanac of Clinical Medicine, 2019, vol. 47(5), pp. 383-92. (In Russ.). DOI: https://doi.org/10.18786/2072-0505-2019-47-055

[38] Yu.S. Landyshev, "Mechanisms of action and main therapeutic effects of glucocorticoids" [Mekhanizmy deystviya i osnovnyye terapevticheskiye effekty glyukokortikoidov], Amur Medical Journal [Amurskiy meditsinskiy zhurnal], 2014, vol. 1(5), pp. 10-29. (In Russ.).

[39] P. Apsangikar, S. Chaudhry, M. Naik, S. Deoghare and J. Joseph, "Comparative study for efficacy and safety of biosimilar infliximab in patients with active rheumatoid on a stable dose of methotrexate", J Arthritis Rheumatol Res, 2018, vol. 1(1), p. 101.

[40] K.K. Jørgensen, I.C. Olsen, G.L. Goll, M. Lorentzen N. Bolstad, E.A. Haavardsholm, K.E.A. Lundin, C. Mørk, J. Jahnsen and T.K. Kvien, "Switching from originator infliximab to biosimilar CT-P13 compared with maintained treatment with originator infliximab (NORSWITCH): a 52-week, randomised, double-blind, non-inferiority trial", The Lancet, 2017, vol. 389(10086), pp. 2304-2316. DOI: http://dx.doi.org/10.1016/S0140-6736(17)30068-5

[41] I.O. Smitienko and P.I. Novikov, "Biosimilars in the treatment of rheumatic diseases: pro and contra" ["Bioanalogi v lechenii revmaticheskikh bolezney: pro et contra"]. Clinical pharmacology and therapy [Klinicheskaya farmakologiya i terapiya], 2019, vol. 28(4), pp. 5055. (In Russ.). DOI: https://doi.org/10.32756/0869-5490-2019-4-50-55

[42] J.P. Brown, K. Wing, S.J. Evans, K. Bhaskaran, L. Smeeth and I.J. Douglas, "Use of real- world evidence in postmarketing medicines regulation in the European Union: a systematic assessment of European Medicines Agency referrals 2013-2017”, BMJ Open, 2019, vol. 9, e028133. DOI: https://doi.org/10.1136/ bmjopen-2018-028133 